\title{
How do mega-bank merger policy and regulations contribute to financial stability? Evidence from Australia and Canada
}

\section{Caner Bakir}

\begin{abstract}
Although the role of financial regulatory failures in the global financial crisis (GFC) has been explored extensively in the post-GFC literature, our knowledge of the role of bank merger and takeover policy and regulation in reinforcing financial stability is limited. Based on an exploratory case study of Australia, which is examined in comparison to Canada, this article argues that competition policy and regulation contributed to financial stability by insulating the largest Australian and Canadian banks from domestic or foreign hostile takeover threats, and by limiting their asset size, and thus their internationalization and interconnections with the global banking community.
\end{abstract}

\section{Introduction}

The global financial crisis (GFC) has shown that short-termism, i.e. "hyperactive behavior by [bank] executives whose corporate strategy focuses on restructuring, financial reengineering or mergers and acquisitions at the expense of developing the fundamental operational capabilities of the business", coupled with the bonus culture of investment bankers and inadequate financial regulation and supervision leads to excessive risk-taking in bank lending, trading and investment, generating financial instability (Kay 2012, 10). Thus, the role of prudential regulatory and supervisory and corporate governance failures have been explored extensively following the GFC (Barth, Caprio, and Levine 2008; Gamble 2009; Engelen et al. 
2011; Admati and Hellwig 2013). Unsurprisingly, financial regulatory reforms (Young 2013) and corporate governance reforms (Kirkpatrick 2009; Bebchuk and Spamann 2010) became salient issues in the post-GFC era. However, the previous studies ignore the role of competition policy and regulation in enhancing financial stability.

Australia and Canada were the only developed Liberal Market Economies (LMEs) which had the most resilient banking system among developed OECD countries that survived the GFC (OECD 2010b, 8). More interestingly, among OECD countries, notably only Australia and Canada prohibit mergers between the largest domestic banks via government policy and regulation (for a comparative analysis, see Mathewson and Quigley 2003, 121-135). ${ }^{1}$

Do bank merger and takeover policies and regulations that shelter the largest domestic banks from domestic or foreign hostile takeovers contribute to financial stability? If so, how? This article searches for the answers to these questions by exploring and explaining the potential and limit of merger and takeover policy and regulation in informing prudent bank behavior and financial stability.

Based on the comparative analyses of Australia and Canada, this article argues that the competition policy and regulation were among the key factors that reinforced prudent banking and financial stability in these countries. This was due to two main reasons. First, they sheltered Australian and Canadian bank managers from domestic or foreign hostile takeover threats, the presence of which encouraged short-termism and excessive risk-taking in financial markets. They represent obstacles to the market for corporate control (i.e., equity markets did not facilitate hostile corporate takeovers) in the largest Australian and Canadian banks. Second, they limited the largest domestic banks' asset size, and thus their internationalization and

\footnotetext{
${ }^{1}$ The four largest Australian banks included ANZ, Commonwealth Bank of Australia, National Australia Bank Limited and Westpac Banking Corporation. The five largest Canadian banks included Toronto-Dominion Bank, Bank of Nova Scotia, Royal Bank of Canada, Bank of Montreal and Canadian Imperial Bank of Commerce.
} 
interconnections with the global banking community, which largely engaged in sub-prime lending and Collateralized Debt Obligations (CDOs). The point being made here is not that financial stability in Australia and Canada during the GFC was entirely due to bank merger policy and regulation. Rather, it is that their influence on bank behavior, which contributed to financial stability, has often been unnoticed or ignored in the past literature.

This article adopts an exploratory case study method. This is because it examines the phenomenon in its real-life context; investigates why and how questions, and benefits from multiple sources of evidence. The method of data collection during the research was qualitative, which comprised of a combination of interviews and written sources. A series of 60 minute semi-structured elite interviews with open-ended questions were conducted in Sydney and Melbourne in July $2010 .^{2}$ The interview participants provided critical and valuable information concerning financial stability in Australia and Canada. Interview transcripts were analyzed using NVivo software to code and identify themes, and to analyze the data in depth. The interviews were augmented by an extensive review of the primary and secondary written sources.

This article proceeds as follows. Section 2 provides an overview of previous research on bank concentration and financial stability. Section 3 overviews mega-bank merger policy and regulation in Australia and Canada. Section 4 discusses the potential of bank merger policy and regulation in enhancing financial stability in these countries. Section 5 reviews their limits.

\footnotetext{
${ }^{2}$ Interview participants held very senior positions in Australian banking and finance, treasury, central banking and regulation. They included current Governor of Reserve Bank Australia (RBA), a former RBA governor who also served as a Treasurer, two RBA deputy governors, executive chairman of Australian Prudential Authority (APRA) who also served as a former RBA deputy governor, General Manager of APRA, A board member of Australia and New Zealand Banking Group Limited (ANZ) who was a former RBA governor, Chief Executive Officer of Promontory Financial Group who also previously served as the inaugural chairman of APRA, member of Financial System Inquiry (FSI, 1997) and a deputy governor at RBA, a global investment strategist at BNY Mellon who also served as a senior advisor to a former Prime Minister, and a Partner at Deloitte Access Economic who also served as a member of FSI.
} 
Section 6 concludes with key findings, limitations, policy implications and directions for future research. 


\section{An overview of the literature}

Before the GFC, it was widely held that the market for corporate control disciplines bank managers through hostile takeover threats in share markets, encouraging them to improve their performance in order to avoid a takeover and the subsequent loss of employment (Manne 1965, Romano 2005). The GFC, however, has shown that when there is strong competition for corporate control in banking, excessive risk-taking driven by short-term market indicators is more likely (Brummer 2008, chap. 2-3, 6; Mason 2009, chap. 4; Augar 2010, chap. 1; Tett 2009). The formal institutions of a corporate remuneration system and corporate governance may encourage and reward excessive risk-taking behavior in banking, contributing to systemic risk (Kirkpatrick 2009; Bebchuk and Spamann 2010). Bankers informed by a bonus culture, for example, have a strong incentive to monitor short-term market-based performance indicators, such as higher share prices, higher price earning and return on equity ratios. The U.S. and UK had several examples of such behavior. Major governance failures within banks are characterized by the short-term imperatives typical of LMEs, such as the "acute short-termism and serious hyperactivity" present in the lead-up to the GFC (Kay 2012, 19; see also House of Commons Treasury Committee 2009, 3; Financial Services Authority 2009, 80). However, we do not know whether competition policy and regulation prohibiting domestic or foreign takeover of the largest banks reinforce prudence and stability in the banking sector.

Further, Australia and Canada have "highly concentrated banking sectors" wherein "four major banks dominate the sector in Australia, where also a few small domestic and foreign banks are present; six banks dominate the whole system [90 percent] in Canada" (OECD 2010a, 26; Laker 2009). Thus, the resiliency of Australia and Canada during the GFC seems to suggest that more concentrated banking sectors are more resilient than less concentrated ones such as those in the U.S. and Germany (FitchRatings 2012, 5). However, "the big impact that the crisis 
has had on other countries, such as [United Kingdom], Switzerland and the Netherlands, with very concentrated financial systems shows that the opposite is also possible" (OECD 2010a, 9).

Unfortunately, finance theory and academic evidence on bank concentration, competition and financial stability offer limited guidance for policymakers. As the OECD notes, "[it] is not clear whether excessive competition contributed to the recent financial crisis. Both the country experiences and the academic debate suggest that concentration and competition have ambiguous effects on financial stability" (Ibid). For example, competition-fragility or concentration-stability, and competition-stability or concentration-fragility represent two competing views on this topic in the finance literature (for an overview see OECD 2010a, 181188; Carletti and Hartmann 2002; Claessens and Laeven 2004; Casu and Girardone 2006). The concentration-stability view holds that a concentrated banking sector with few banks is more stable than a banking sector with many banks. The so-called "charter value hypothesis" holds that banks that earn monopoly rents through their market power have higher charter value which deters excessive risk-taking behavior. This is because it raises the opportunity cost of bankruptcy. Banks exercise their oligopolistic powers to boost their profits, which beef up bank capital, and as they earn more monopoly in deposit markets, they are less likely to fail (Allen and Gale 2000; Hellman, Murdoch and Stiglitz 2000; Repullo 2003). It is assumed that regulators supervise these few banks more closely. Some international evidence offers support to this view that banking crises are less likely to occur in countries with more concentrated banking systems (Beck, Demirguc-Kunt, and Levine 2006). Banks with high market concentration generally have less risk exposure (Berger, Klapper, and Turk-Ariss 2009). In a similar vein, the competition-fragility view argues that high competition encourages excessive risk taking among banks to earn higher profits (Allen and Gale 2000). In contrast, the concentration-fragility or competition-stability view states that as a banking system becomes more competitive and less concentrated, it becomes less fragile and more stable as competition 
reduces risk taking (Boyd and De Nicolo, 2005; Schaeck, Cihak, and Wolfe 2009; Boyd, De Nicolo, and Jalal 2010).

Finance research findings on whether mergers, and thus concentration, lead to better risk diversification thereby reducing banks' risk is also mixed (for overviews, see Carletti and Hartmann 2002; Hughes and Mester 1998). On the one hand, several studies argue that "[1]arge banks tend to be more diversified, in terms of both geography and products, and are therefore better positioned against geographic and product risk" (OECD 2010a, 22). On the other hand, other studies demonstrate the opposite result, showing that "[g]reater diversification makes large banks readjust their portfolios towards greater risk" by lowering the costs of risk management (Ibid).

Recent research also highlights how interconnectedness among banks plays a major role in generating financial crises (Espinosa-Vega and Russell 2015; Liu and Quiet 2015; Peltonen, Rancan, and Sarlin 2015). This is because banks are connected to each other where stresses in one part of the financial system is transmitted to other parts of the system, resulting in financial stability risks. Liu and Quiet $(2015,2)$ notes that "The financial crisis in 2008 was particularly severe because a considerable number of banks, operating in different countries and in different markets, all ran into difficulties at the same time".

These mixed theoretical perspectives, based on evidence from quantitative research on the links between bank concentration, competition, interconnectedness and financial stability, call for further qualitative insights into the various sources of prudent bank behavior and financial stability.

\section{Mega-bank Merger Policy and regulation in Australia and Canada}

On 18 March 1997, the Wallis Inquiry, the third major financial system inquiry (FSI) to review the Australian financial system, made 115 recommendations to the government (for a 
political economy discussion, see Bakir 2003). One of the key recommendations of the Wallis Committee was the removal of the "six pillars" policy, which blocked mergers between the largest four banks or the largest two insurance companies. Instead of doing so, the government replaced the "six pillars" policy with the "four pillars" policy, which allowed mergers between any one of the big banks and the two big insurance companies, while continuing to block major bank mergers. The then-Treasurer made it clear that he intended to retain veto power granted under the Banking Act 1959 (Canberra Times 1997). The "four pillars" policy was a political decision and the key Government intervention preventing the major banks from merging with one another. It was the outcome of constellations, conflicts, coalitions and bargaining among various actors in the Australian political economy (Bakir 2005).

Australia also imposes legal restrictions on the holding of large blocks of shares among financial corporations, which limit the acquisition of domestic banks by another domestic or foreign bank (FSI 1997, chap. 10; Gouvin 2001). There are three main formal institutional sources of mega-bank merger policy in Australia. Specifically, Section 63 of the Banking Act 1959, the Financial Sector (Shareholdings) Act 1998, and the Foreign Acquisitions and Takeovers Act 1975 provide the institutional framework that insulates major banks from domestic or foreign hostile takeover threats.

Approval for a merger or acquisition proposal can only be granted if a bank satisfies the Treasurer that the transaction is in the national interest. The Banking Act only states that the Treasurer's consent shall not be unreasonably withheld, but does not provide further guidance on exactly how the Treasurer should exercise his discretion. Practically speaking, the Treasurer takes a number of factors under advisement, including "any prudential considerations, the potential efficiency gains resulting from any rationalization, and any potential losses resulting from reduced competition in the financial sector" (Treasury 1996, 143). 
The Financial Sector (Shareholdings) Act 1998, requires the Treasurer's consent for any party wishing to buy more than $15 \%$ of a bank or insurance company's voting rights. This formal institution allows the government to maintain the "four pillars" policy. Accordingly, these banks do not pose a hostile takeover threat to one another in their domestic market. In a similar vein, the Foreign Acquisitions and Takeovers Act 1975 protects Australian banks from foreign takeover threats. A foreign takeover of an Australian bank is subject to approval of the Treasurer, guided by national interest concerns under this Act. This legal institution makes a foreign takeover of one of the major banks virtually impossible (FSI 1997, chap. 10).

Moreover, Australian banks do not face strong competition from foreign banks in retail banking. This is mainly due to institutional and organizational-level constraints that limit foreign bank competition. As a part of Australia's depositor protection measure, foreign banks coming "into Australia as branches are not allowed to compete for retail deposits of an initial balance below A $\$ 250,000 ”$ (Senate 2011, 184). Further, they have limited agency-level capabilities to establish a nation-wide banking branch network in a physically large continent. Accordingly, the major banks benefit from restrictions that lessen potential competition in the retail deposit market (Bakir 2004).

The Australian position on mega-bank merger policy and regulation were, in terms of the international experience, unusual in many respects, with the exception of Canada. In Canada, a "widely held rule" was enacted in 1967 to protect Canadian banks from hostile takeovers, "especially by American banks" (Gouvin 2001, 400). It ensures that a single shareholder, whether foreign or domestic, cannot own more than $20 \%$ of voting rights in a large bank. Moreover, this rule states that no person or group may control $10 \%$ or more of a bank without the approval of the Minister of Finance. In the words of Gouvin "The widely held rule 
acts like a statutory poison pill, making acquisition of a Schedule I [Canadian] bank impossible" (Gouvin 2001, 400, 407).

In 1998, the Royal Bank of Canada and the Bank of Montreal proposed a merger, and the Canadian Imperial Bank of Commerce and Toronto-Dominion Bank announced their intention to merge. Although the McKay Task Force on the Future of the Canadian Financial Sector recommended in 1996 that the policy prohibition on mega-mergers among financial institutions should be abandoned, Paul Martin, the then Finance Minister, blocked the mergers on 14 December 1998 (for a political economy discussion, see Tickell 2000). He announced that "the mergers were not in the best interest of Canadians and would not be allowed because they would lead to an unacceptable concentration of economic power in the hands of fewer and very large banks; a significant reduction of competition; and reduced policy flexibility for the government to address potential future prudential concerns" (Martin 1998). Like the four largest Australian banks, the five largest Canadian banks do not face domestic or foreign takeover threats.

\section{The potential of bank merger policy and regulation in enhancing financial stability in Australia and Canada}

\section{Australia}

"Major banks are a result of a series of bank mergers over the past 150 years" (Senate 2009, 81). ${ }^{3}$ In this environment, Australia's oligopolistic market structure produced a competition policy, the "four pillars" policy, which was the Australian government's distinctive

\footnotetext{
${ }^{3}$ It should be noted that "takeovers of regional and State banks were the key avenues for the largest four banks to consolidate their economic power" (Bakir 2004, 76). Most recently, the major banks continued increasing their market share of deposit taking financial firms' assets at about 10 percentage points between 2005 and 2009. As Donovan and Gorajek $(2011,32)$ notes " $[\mathrm{t}]$ his was partly due to two acquisitions of smaller banks in late 2008: Westpac acquired St. George Bank in December 2008, which was the fifth largest bank at the time, and Commonwealth Bank acquired the foreign-owned Bankwest in October 2008, which was the eighth largest bank at the time."
} 
response and intervention in corporate competition on public policy grounds. It was based on the idea "that a merger between any two of the four major banks would likely be followed by a merger of the remaining two, giving rise to an effective duopoly" (Senate 2009, 55).

However, this paper finds that senior interviewees also considered this competition policy as one of the key contributors to financial system stability in Australia in the lead-up to the GFC. They noted two main effects of the "four pillars" policy that reinforced bank prudence and financial stability. First, the "four pillars" policy has also reduced incentives for excessive risk-taking arising from unrestrained competition for corporate control via hostile takeovers. As Ian Macfarlane, former Governor of Reserve Bank of Australia (RBA) and board member of ANZ Bank, notes:

Intense competition amongst financial institutions always leads to financial instability. ... The most intense form of competition is the competition for corporate control. Now, in Australia the big four knew they couldn't take each other over so when they went to work in the morning none of those big four banks, which dominate the Australian banking system, was driven to extremes to get their earnings up. So, they were able to look at some of the things that were happening around the world and say 'I do not need to go into sub-prime lending. I do not need to do any of those risky things'. So they did not (Interview 12 July 2010).

Throughout the interviews, a consistent pattern emerged showing that interviewees viewed the "four pillars" policy as one of the contributors to financial stability in the Australian banking system. As noted by Don Russell, a global investment strategist at BNY Mellon and a former Treasury officer and a senior adviser to the Prime Minister:

... "four pillars" policy which prevented the banks from feeling under [hostile] takeover threat because probably our banks would have behaved very much like the English banks, I think, if they thought that four was going into two. They would have tried to build up their balance sheets, which would have meant they would have been more geared, more leveraged (Interview 5 July 2010).

Further, most of the interviewees shared the view that the four pillars policy "is doing what it has always done and that is compromise efficiency, competition, growth and 
internationalization [of the major banks] in the interests of stability", as noted by Ian Harper, a

Partner at Deloitte Access Economics and a former member of Wallis Committee (Interview

15 July 2010; see also Senate 2011, 183).

Second, the policy prevented the creation of national champions that could have competed globally by limiting increases in the asset size of major banks. In the words of Jeffry Carmichael, a former member of the Wallis Committee, the former inaugural Chairman of Australian Prudential Regulation Authority (APRA) and Chief Executive Officer of Promontory Financial Group:

The basic idea of [the four pillars policy] is the four big banks cannot merge. And if that rule were taken off tomorrow there would be a flurry of takeover activity and I suspect within five years we would only have two banks trying to become big enough to compete more effectively internationally. Australia is a small market. ... They are big in this market but you say well how do they stack up against the big banks in the world? They're still only second tier (Interview 16 July 2010).

Unsurprisingly, the "four pillars" policy reduced the major banks' internationalization and interconnectedness with the global banking community which largely engaged in sub-prime lending and CDOs. As noted by Harper,

The "four pillars" policy has been vindicated, people say, by the global financial crisis because of course it made our banks much more stable. Arguably if they [i.e., the largest four banks] had been more competitive, bigger and more internationally engaged, more globalized, they would have, quite arguably, been in a similar situation to the banks in Britain and Europe. ... So, we don't have globalized banks, therefore we didn't catch the globalized disease (Interview 15 July 2010, my italics).

\section{Canada}

In regard to financial and competition regulations and policies, most of the Australian interviewees shared the view that "Canada is a bit like us" (Carmichael, Interview 16 July 2010). Like Australia, financial stability arising from bank merger policy in Canada came in 
two forms. First, like the "four pillars" policy in Australia, the "widely held rule" enabled Canadian banks to avoid taking excessive risks due to the pressure of a potential hostile takeover. Macfarlane offers a comparative perspective:

So Canada and Australia are the only two that got through of the OECD countries...because they had a limit on the competition for corporate control. So, even though there was a lot of competition in various aspects of banking there wasn't the really cut-throat desperate competition that you get if you think you will get taken over tomorrow by your competitor. That, to me, is the crucial difference between the two countries that got through it ok and the other [countries] that didn't get through it ok (Interview 12 July 2010).

Russell makes a similar point,

So, when the [global financial] crisis came, our banks had better capital, probably a much closer control over their risks and it was a combination. .... [the] other country that does quite well during this period is Canada and Canada has a similar sort of banks, but also a similar sort of policy... there is a conscious policy of maintaining the number of banks in Canada (Interview 5 July 2010).

In a similar vein, Howard Green, one of the founders of Canada's Business News Network, observes that: "It's not inconceivable that if they [the largest Canadian banks] had merged, they would have become deeply involved in the U.S. sub-prime housing market, perhaps by buying a dodgy American financial institution, creating a banking crisis in Canada" (Green 2013). Eamonn Fingleton (2012), the former editor of Forbes and the Financial Times, also notes that "The "widely held" rule has also greatly curtailed foreign banks' expansion efforts and this has rendered the Canadian banking market an island unto itself. ... 'Innovative' U.S. banking practices are thereby stopped at the border and without the complication of having to deal with foreigners' expectations and pressures, Canadian regulators maintain a firm grip" (see also IMF 2014, 24). 
Second, like Australia, the legal and policy restrictions limited Canadian banks' asset size and thus their internationalization and interconnectedness, contributing to Canadian financial stability in the lead-up to the GFC. As PricewaterhouseCoopers $(2008,2)$ notes, Canadian banks could not match the size of global banks due to mega-bank merger policy which limited their excessive levels of risk exposure before the GFC: "Historically Canadian banks have been restricted from bulking up to rival the size of global banks. Ironically, their constrained size may have protected them from some of the excessive levels of exposure experienced by some global banks" ( Fingleton 2012; Green 2013). From a comparative perspective, the competition regulation limiting the largest banks' size through the prohibition of domestic mergers in Australia and Canada, along with India and Malaysia, resulted in a relatively low degree of exposure to risks in the international banking sector (e.g., relatively low international financial claims and liabilities as percent of total assets) contributing to financial stability in the lead-up to the GFC (IMF 2012, 107-108). Unsurprisingly, none of the major banks in Australia and Canada have been listed as global systemically important banks by the Financial Stability Board (Financial Stability Board 2015).

These findings raise a relevant question: Were bank merger policy and regulation the only contributors to prudent bank behavior and financial stability in Australia and Canada? Addressing this question necessarily depends on insights from a range of studies in the past literature.

\section{The limit of merger policy and regulation in informing prudent bank behavior and financial stability in Australia and Canada}

Financial stability in Australia and Canada during the GFC was not entirely due to bank merger policy and regulation. As Glenn Stevens, Governor of the Reserve Bank of Australia, notes, Australian and Canadian banks were resilient during the GFC because they were 
"profitable and well capitalized by private investors" and their "holdings of the complex securities at the center of the crisis were modest by international standards"; additionally, they "had more conservative lending practices in their home markets than their counterparts in the United States and the United Kingdom” (Stevens 2009, 42; see also IMF 2014, 18; Martin 2012, McDonald and Morling 2011; Kennedy 2009).

There were several macro and micro-level contextual factors that contributed to these outcomes in the lead-up to the GFC. For example, the macroeconomic context contributed to the financial stability in both countries. The outperformance of banks is driven in part by Australia's and Canada's comparatively high investment to GDP ratio and favorable commodity cycle that contributed to real GDP growth, a real increase in wealth, low unemployment and real interest rates, and a rise in housing prices (IMF 2006, 2008; Martin 2012; McDonald and Morling 2011; Kennedy 2009). This macroeconomic structure also reinforced incentives for banks to concentrate their assets in national markets and to focus mainly on lucrative domestic lending, in particular residential housing loans, rather than the high-risk sub-prime loans available in overseas markets. As Stevens notes "There was plenty of money to be made doing common, everyday banking at home" (Interview 2 July 2010). Similarly, David Dodge, former Governor of Bank of Canada (BoC) notes that: "You had a set of banks that had essentially very profitable domestic commercial banking franchises. They had to be pretty bad in their other businesses to lose money overall” (Cited in Freeland 2010).

In a similar vein, the oligopolistic market structure has been among the main sources of "modest returns on assets, and high returns on equity" in Australia (IMF 2006, 6). Charles Littrell, General Manager at APRA, offers a representative vignette about market structure, bank profitability and risk-taking:

We tend to [think] the banks are good at profitability because they run the oligopoly and extract profits from that. They have tended to be strategically reasonably focused on 
what they're doing and so they're not taking all the strategic risk or a lot of credit risk which is what kills a lot of banks and trading terms (Interview 9 July 2010).

In both countries, the "[b]enefits of greater profitability include providing a greater buffer against losses, reducing the incentive to chase market share or higher-risk lending, and potentially increasing access to additional capital should it be required" (FitchRatings 2012, 5). Unsurprisingly, Australian and Canadian banks have a high geographical concentration in their home market and sectorial concentration in retail banking activities with strong financial soundness (i.e., strong profitability, capital adequacy and asset quality) compared to banking sectors in advanced liberal and coordinated market economies (Bakir 2013, 60-68). ${ }^{4}$

In addition to macroeconomic and market contexts, the financial regulatory context was among the factors that reinforced conservative banking and financial stability. In the words of John Laker, executive chairman of APRA, "We have global regulations on capital and in fact we implemented those in a more conservative way in Australia than many other countries" (Interview 9 July 2010). Carmichael offers a comparative perspective, "What we realized very quickly is that all of the discretions that the Basel committee allows, or used to allow, actually create enormous differences in capital treatment so that Australia was easily the toughest on every discretion. Canada wasn't far behind" (Interview 16 July 2010). Both countries "have much stricter regulatory environments; [their] banks' exposure to structural finance products and wholesale activities has been very limited. ... this lower exposure results from more severe and stringent regulatory factors that have reduced the banks' incentives to take risk" (OECD 2010a, 26; IMF 2006).

This conservative regulation has been reflected, for example, in Australian and Canadian banks' Tier One capital which was in common shares and retained earnings in these

\footnotetext{
${ }^{4}$ In contrast to Australian and Canadian banks, the Landesbanken (state-owned regional banks) and commercial banks in Germany operated in a less concentrated and more competitive banking sector. Further, in the absence of a high investment ratio (or lucrative domestic lending opportunities), they channeled relatively high domestic savings offshore and chased risky assets (for a discussion, see Bakir 2013, 76, 78,79).
} 
countries rather than preferred stock, a hybrid of equity and debt in the U.S. and UK (IMF 2009, 213-230). Further, these banks had the lowest non-performing loan to total loans ratio, and the highest bank loan book provisioning ratio for bad and doubtful debts, indicating highly conservative provisioning against loan defaults and strong capital quality among the developed market economies (ibid.). They were also less leveraged than their international peers due to stringent capital regulation that limit the build-up of risk for these banks (Fitch 2012, 8; Lynch 2010, 13). Both countries also impose repayment penalties and full recourse against mortgage borrowers, and do not allow mortgage interest to be deducted, thereby reinforcing prudent borrowing behavior in the mortgage market (Debelle 2008; Min 2010; for international comparison of mortgage regulation, see IMF 2011). Unsurprisingly, Australian and Canadian banks entered the GFC in a sound position and were resilient throughout the crisis due in part to this stringent financial regulation.

However, conservative financial regulation and supervision were not the only contributors to bank prudent banking and financial stability in these countries. For example, there was no regulatory or supervisory limit on these banks' engagement with structured credit securities or sub-prime mortgages. However, in contrast to 13 per cent share of sub-prime mortgages in the U.S. mortgage market in mid-2007, their closest equivalents in "Australia and Canada accounted for around 1 per cent and less than 5 per cent of their mortgage markets, respectively" (Stevens 2009, 42). Then it is legitimate to ask: If regulations did not prohibit the sale or purchase of CDOs and mortgage-backed securities in Australia and Canada, why did Australian and Canadian banks have relatively low exposure to these instruments compared to the U.S. and UK? This was due to the banking business model that informed conservative banking practices. 
The dominant business model in Australian and Canadian banking was based on retail banking, which reinforced commitments to the credit culture and the traditional originate-andhold model, rather than the bonus culture and originate-and-distribute model of investment banking, which in turn contributed to financial stability. As Harper emphasizes, "our [Australian] banks have been so conservative that the boards have always opted for somebody with retail banking credentials as opposed to investment banking credentials" (Interview 15 July 2010; Garnaut 2009, 142-143). Thus, in the words of Philip Lowe, Deputy Governor of RBA, "a culture of risk management developed around interest rate and exchange rate risk" (interview 2 July 2010). In a similar vein, Mark Carney, former Governor of BoC, states that "Canadian bankers are still bankers. They still - through the organisations and up to the top of the organisation - are proficient at managing credit risk and market risk ... they have retained a banking culture through[out] the organisation" (cited in Freeland 2010; Martin 2014; Bordo, Redish, and Rockoff 2011; for international comparisons, see Bebchuk and Spamann 2010; Kirkpatrick 2009). Unsurprisingly, like conservative regulation, a conservative retail banking culture has informed the prudent decisions and actions of bankers in these countries. As Harper notes “We didn't need to buy assets that we didn't understand. Our banks lent, predominantly, in Australia to borrowers who they'd all been lending to, who they understood. We didn't have to go and do something exotic in foreign markets" (Interview 15 July 2010). Similarly, Ed Clarke, CEO of Toronto-Dominion's notes that “[asset-backed securities] became too complex. If I cannot hold them for my mother-in-law, I cannot hold them for my clients" (cited in Kravis, 2009).

This conservative behavior has been reflected in Australian and Canadian banks' key activities and sources of income, which were largely based on retail banking rather than marketbased banking. In terms of bank assets, domestic lending constituted two-thirds of the total bank 
assets whilst deposits accounted for about 50 per cent of total bank liabilities in 2010 in Australia (see Donovan and Gorajek 2011, 32). Not surprisingly, net interest income and banking fees constituted nearly 70 per cent of banks' operating income and income from securities trading constitutes about five per cent of banks' total income (ibid). Specifically, “interest income from primarily mortgage and consumer lending accounts for about two-thirds of the major banks' total income, reflecting their focus on retail lending activities" (Financial Stability Board, 2011: 9). Similarly, traditional banking activities (i.e., deposit taking and lending) 'accounted for about three-quarters of Canadian banks' total gross income [before the GFC]...whilst interest income from lending ... represented more than half of the banks' total income" and "non-traditional, market-based activities accounted for only 15 per cent of Canadian banks' total gross income in 2006" (Leblond 2013, 204-206; see also Calmès and Liu 2009).

In terms of bank liabilities, Canadian, and to a lesser extent Australian, banks relied on funding from national deposit bases rather than wholesale funding (OECD 2010a, 10). It should also be noted that Australian banks relied more on wholesale funds, whilst Canadian banks' funding was dominated by retail deposit funding (Bakir 2013, 71-73). This was because Australia, as a current account deficit country, had a lower savings ratio than investment ratio. In contrast, Canada, as a current account surplus country, had a higher savings ratio than investment ratio. Thus, Australian banks' domestic and offshore wholesale funding accounted for over 50 per cent of total liabilities, where about 60 per cent was offshore (Takats and Tumbarello 2009, 6). They diversified their funding basis and funded their lending activities through retail deposits (40 per cent) and domestic and offshore wholesale funding (53 per cent) rather than securitization (six per cent) as of December 2007. The Australian banks' relative reliance on offshore capital markets for funding "imposed market discipline over banks to 
maintain good credit rating" to access offshore wholesale funds at reasonable costs, remarked John Phillips, former RBA deputy governor (interview 5 July 2010, Sydney).

Ratnovski and Huang $(2009,9)$ also argue that Canadian banks relied heavily on depository funding from retail deposits rather than wholesale funding (i.e., short-term money market and longer-term debt and equity issuance), which was considered as the key determinant of their resilience during the GFC: "the funding structure [sic] is an important predictor of bank resilience during the turmoil [GFC] rather than bank capitalization and liquidity... wholesale financing can distinguish sound banks". In a similar vein, Leblond $(2013,215)$ concludes that the Canadian outperformance compared to the United Kingdom and the U.S. during the GFC "rests squarely on its low exposure to market-based activities, both on the asset and liability sides of the balance sheet" which sheltered Canadian banks from being exposed to the "toxic" financial products of investment banking (see also Hardie and Maxfield 2013). The Australian experience also confirms this finding.

In addition to the common regulatory and policy obstacles to the market for corporate control, the discussion in this section shows that there were multiple causal mechanisms operating at the macro-economic, market, and institutional levels, and at the micro organizational (i.e., business model based on retail banking) and individual (i.e., conservative regulators and retail bankers) levels that reinforced conservative bank behavior maintaining financial stability in Australia and Canada.

\section{Conclusion and policy implications}

This article highlights the much neglected role of bank merger policy and regulation, and its potential and limit in informing prudent bank behavior and financial stability with special reference to the Australian case examined in comparison with Canada. 
Based on interpretive accounts of causal mechanisms and evidence from written sources, three interrelated conceptual and empirical insights emerge from this study. First, this article argues that bank merger policy and regulation which prohibit domestic of foreign mergers or hostile takeovers have been important instruments of blunting short-term market pressures on bank managers. This finding lends support to the competition-fragility or concentration-stability view. It also shows that effective bulwarks against the short-termism of financial markets are not limited to block shareholdings or cross shareholdings (see, for example, Culpepper 2005, 185). Second, merger policy and regulation limited the interconnectedness of the largest Australian and Canadian banks to the global financial system in the run-up to the crisis by curbing their asset size growth. This finding supports the view that less interconnected banking systems are more stable. Third, merger policy and regulation have been among the various complementarities that informed conservative bank behavior and financial stability. This finding contributes to previous research on sources of financial stability by highlighting the need to devote greater analytical attention to multiple causal mechanisms and the links between complementarities arising from macro and micro-level contexts that inform conservative (opportunistic) bank behavior, and financial stability (instability).

National and international organizations and policy makers can also draw insight from these analyses. They should avoid adopting or eschewing comprehensive conclusions for financial stability solely on the basis of corporate governance, financial regulation, competition rules and policies, or bank funding structure. Instead, it would be better for them to consider the causal mechanisms arising from the characteristics of various context-dependent multiple variables and their interactions with agency. Indeed, future research on the policy design (Howlett 2009, 2014) and financial sector reform in the post-GFC era needs "a better understanding of how specific causal processes may be designed or managed in practice 
through aligning and reinforcing various policies and incentives thereby producing competitive advantages for public and private sector actors, and comparative advantages for nations that would not otherwise occur" (Bakir and Woo 2016, 201-202).

This paper also has several implications for future research. For example, the relative importance of various factors in informing bank behavior and financial stability may be further investigated by a quantitative research design or by mixed methods such as qualitative comparative analysis. Additional cross-national case studies may also further contribute to our understanding of cross-national variation in bank behavior and financial stability.

\section{References}

Admati, Anat, and Martin Hellwig. 2013. The Bankers' New Clothes: What's Wrong with Banking and What to Do about It. Princeton University Press.

Allen, Franklin, and Douglas Gale. 2000. Comparing Financial Systems. Cambridge: Massachusetts Institute of Technology.

Augar, Philip. 2010. Reckless: The Rise and Fall of the City. London: Vintage Books.

Bakir, Caner. 2003. "Who Needs A Review Of The Financial System In Australia? The Case of the Wallis Inquiry." Australian Journal of Political Science 33 (3): 511-534.

Bakir, Caner. 2004. "Bank Powers and Public Resistance to Mega Bank Mergers." Journal of Australian Political Economy 54: 67-93.

Bakir, Caner. 2005. "The Exoteric Politics of Bank Mergers in Australia.” Australian Journal of Politics and History 51 (2): 235-256.

Bakir, Caner. 2013. Bank Behaviour and Resilience: The Effect of Structures, Institutions and Agents. Palgrave Macmillan Studies in Banking and Financial Institutions. Palgrave Macmillan.

Bakir, Caner. 2017. "How can interactions among interdependent structures, institutions, and agents inform financial stability? What we have still to learn from global financial crisis", Policy Sciences (forthcoming).

Bakir, Caner. and Woo, J.J. 2016. "Financial sector reform and policy design in an age of instability", Policy and Society, 35(3): 193-204.

Barth, James. R., Gerard Jr. Caprio, and Ross Levine. 2008. Rethinking Bank Regulation: Till Angels Govern. Cambridge: Cambridge University Press.

Bebchuk, Lucian A., and Holger Spamann. 2010. "Regulating Bankers' Pay." Georgetown Law Journal 98 (2): 247-287.

Beck, T.; A. Demirguc-Kunt; and R. Levine. 2006. "Bank Concentration, Competition, and Crises: First Results." Journal of Banking and Finance, 30, 1581-1603. 
Berger, A. N.; L. F. Klapper; and R. Turk-Ariss. 2009. "Bank Competition and Financial Stability."Journal of Financial Services Research, 35, 99-118.

Bordo, Michael D., Angela Redish, and Hugh Rockoff. 2011. Why Didn't Canada Have a Banking Crisis in 2008 (or in 1930, or 1907, Or...)? National Bureau of Economic Research DAE No 17312.

Boyd, J. and G. De Nicoló (2005). — The theory of bank risk-taking and competition revisited,॥ Journal of Finance, 60 (3), 1329-1343.

Boyd, J. H.; G. De Nicol'o; and A. M. Jalal. 2009. "Bank Competition, Risk and Asset Allocations." International Monetary Fund Working Paper 09/143.

Brummer, Alex. 2008. The Crunch: How Greed and Incompetence Sparked the Credit Crisis. London: Random House Business Books.

Calmès, C., Liu, Y., 2009. "Financial structure change and banking income: A Canada-U.S. comparison". Journal of International Financial Markets, Institutions and Money 19, 128-139.

Campbell, John. L. 2011. "The US Financial Crisis: Lessons for Theories of Institutional Complementarity." Socio-Economic Review 9 (2): 211-234.

Canberra Times. 1997. April 10.

Carletti, Elena, and Philip Hartmann. 2002. Competition and Stability: What's Special About Banking? European Central Bank Working Paper Series No. 146.

Casu, Barbara, and Claudia Girardone. 2006. "Bank Competition, Concentration And Efficiency In The Single European Market." Manchester School 74 (4). University of Manchester: 441-468.

Claessens, Stijn, and Luc Laeven. 2004. "What Drives Bank Competition? Some International Evidence." Journal of Money, Credit and Banking 36 (3): 563-583.

Culpepper, Pepper D. 2005. "Institutional Change in Contemporary Capitalism: Coordinated Financial Systems since 1990.” World Politics 57 (02): 173-199.

Debelle, Guy. 2008. "A Comparison of the US and Australian Housing Markets.” RBA Bulletin, June, 35-46.

Donovan, B. and Gorajek, A. 2011. "Developments in the Structure of the Australian Financial System", RBA Bulletin, June, 30 -40.

Engelen, Ewald, Ismail Erturk, Julie Froud, Sukhdev Johal, Adam Leaver, Michael Moran, Adriana Nilsson, and Karel Williams. 2011. After the Great Complacence: Financial Crisis and the Politics of Reform. Oxford: Oxford University Press.

Espinosa-Vega, Marco A, and Steven Russell. 2015. Interconnectedness, Systemic Crises and Recessions. IMF Working Paper No. 15/46.

Financial Services Authority. 2009. The Turner Review: A Regulatory Response To the Global Banking Crisis. London: Financial Services Authority.

Fingleton, Eamonn. 2012. "The Mysteries of Finance: What Do Canadians Know That Americans Don't?" Forbes, 16. http://www.forbes.com/sites/eamonnfingleton/2012/11/16/the-mysteries-of-financewhat-do-canadians-know-that-americans-dont/\#32d64c48484f.

FitchRatings. 2012. “Australian and Canadian Major Banks.” Special Report, January 30. 
Freeland, Chrystia. 2010. "What Toronto Can Teach New York and London." Financial Times, January 29. http://www.ft.com/cms/s/0/db2b340a-0a1b-11df-8b23-00144feabdc0.html.

Financial Stability Board, 2011. Peer review of Australia: Review Report. 21 September. Available at http://www.fsb.org/2011/09/r_110926b/

Financial Stability Board. 2015. Update of list of global systemically important banks. 3 November. Available at http://www.fsb.org/wp-content/uploads/2015-update-of-list-ofglobal- systemically-important-banks-G-SIBs.pdf

FSI. 1997. Financial System Inquiry Final Report. Canberra.

G-10 (Group of 10). 2001. Consolidation in the Financial Sector. https://www.imf.org/external/np/g10/2001/01/Eng/pdf/file1.pdf.

Gamble, Andrew. 2009. The Spectre at the Feast: Capitalist Crisis and the Politics of Recession. Houdmills: Palgrave Macmillan.

Garnaut, Ross. 2009. The great crash of 2008. Melbourne: Melbourne University Press.

Gouvin, Eric J. 2001. "The Political Economy of Canada's 'Widely Held' Rule for Large Banks." 32 Law \& Pol'y Int'l Bus. 391.

Green, Howard. 2013. "Carney, Politics \& Too Big to Fail Banks." Howard Green, July 3. http://www.bnn.ca/Blogs/2013/7/3/Keeping-Canadian-banks-in-check.aspx.

Hardie, Iain. and Maxfield, Sylvia. 2013. "Market-Based Banking as the Worst of All Worlds: Illustrations from the US and UK", in Iain Hardie and David Howarth (eds.), MarketBased Banking and the International Financial Crisis. Oxford: Oxford University Press, 56-78.

Hellmann, Thomas, Kevin Murdock and Joseph Stiglitz. 2000/ "Liberalization, moral hazard in banking, and prudential regulation: Are capital requirements enough?", American Economic Review 90(1), 147-165.

House of Commons Treasury Committee. 2009. Banking Crisis: Reforming Corporate Governance and Pay in the City. London: The Stationery Office Limited.

Howlett, Michael. 2009. "Governance modes, policy regimes and operational plans: A multilevel nested model of policy instrument choice and policy design", Policy Sciences,42(1), 73-89.

Howlett, Michael. 2014. "From the 'old' to the 'new' policy design: design thinking beyond markets and collaborative governance", Policy Sciences, 47(3), 187-207.

Hughes, Joseph P., and Loretta J. Mester. 1998. "Bank Capitalization and Cost: Evidence of Scale Economies in Risk Management and Signaling." Review of Economics and Statistics 80 (2): 314-325.

IMF. 2006. Australia: Financial System Stability Assessment, Including Reports on the Observance of Standards and Codes on the Following Topics: Banking Supervision, Insurance Regulation, Securities Regulation, and Payment Systems. 06/372. IMF Country Report. Washington.

IMF. 2008. Canada: Financial System Stability Assessment-Update. Washington: IMF.

IMF. 2009. Global Financial Stability Report. Washington: IMF.

IMF. 2011. Global Financial Stability Report. Washington: IMF.

IMF. 2012. Global Financial Stability Report. Washington: IMF. 
IMF. 2014. Canada: Financial Sector Stability Assessment. 14/29. IMF Country Report. Washington: IMF.

Kay, John. 2012. The Kay Review of UK Equity Markets and Long-Term Decision Making. https://www.gov.uk/government/uploads/system/uploads/attachment_data/file/253454/bi s-12-917-kay-review-of-equity-markets-final-report.pdf.

Kelly, Paul. 2009. The March of Patriots: The Struggle for Modern Australia. Carlton: Melbourne University Press.

Kennedy, Steven. 2009. "Australia's Response to the Global Financial Crisis." Speech delivered to Australia Israel Leadership Forum, June 24, 2009.

Kirkpatrick, G. 2009. The Corporate Governance Lessons from the Financial Crisis. Paris: OECD.

Kravis, M-J., 2009. Regulation Didn't Save Canada's Banks, Wall Street Journal, 7 May.

http://www.wsj.com/articles/SB124165325829393691

Laker, John. 2009. "The Global Financial Crisis: Lessons for the Australian Financial System.” Address to the Australian Economic Forum, August 19, 2009. Available at http://www.apra.gov.au/Speeches/upload/03-Aust-Economic-Forum-Opening-Remarks19-Aug-09.pdf.

Leblond, Patrick. 2013. "Cool Canada: A Case of Low Market-Based Banking in the AngloSaxon Worlds", in Iain Hardie and David Howarth (eds.), Market-Based Banking and the International Financial Crisis. Oxford: Oxford University Press, 201-217.

Liu, Zijun, and Stephanie Quiet. 2015. "Banking Sector Interconnectedness: What Is It, How Can We Measure It and Why Does It Matter?" Bank of England Quarterly Bulletin Q, 19.

Lynch, K.. 2010. “Avoiding the Financial Crisis: Lessons from Canada.” Opinions Politiques,Mai: 12-15.

Manne, Henry G. 1965. "Mergers and the Market for Corporate Control", Journal of Political Econom, 73(2): 110-120.

Martin, Paul. 2014. "Taking A Stand On Financial Regulation, Interview at New Economic Thinking." https://www.youtube.com/watch?v=CrG_Y4ZhvZk.

Martin, Paul. 1998. Statement by Honorouble Paul Martin Minister of Finance on the bank merger proposals. 14 December.

Martin, Stephen. 2012. "GFC and Sovereign Risk- Mitigating Measures and Solutions from Down Under." Paper presented at the International Federation of Accountants Conference. Vienna, Austria, March 19-20.

Mason, Paul. 2009. Meltdown: The End of the Age of Greed. London: Verso.

Mathewson, Frank and Quigley, Neal. 2003. "Market Power Thresholds: Theory and Competition Cases Related to Barriers to Entry, Oligopoly and Joint Dominance", Mark $\mathrm{N}$ Berry and Lewis T Evans (eds.), Competition Law at the Turn of the Century: A New Zealand Perspective (Victoria University Press, Wellington), 102-136.

McDonald, Tony, and Steve Morling. 2011. "The Australian Economy and the Global Downturn Part 1: Reasons for Resilience." In Economic Roundup. Treasury: AGPS.

Min, David. 2010. True North: The Facts about Canadian Mortgage System. Washington. 
OECD. 2010a. Competition, Concentration and Stability in the Banking Sector. Paris: OECD. OECD. 2010b. OECD Economic Surveys: Australia. Paris: OECD.

Peltonen, Tuomas A., Michela Rancan, and Peter Sarlin. 2015. Interconnectedness of the Banking Sector as a Vulnerability to Crises. European Central Bank Working Paper Series No. 1866/November.

PricewaterhouseCoopers. 2008. Canadian Banking 2008: Perspectives on the Canadian Banking Industry. Toronto.

Ratnovski, L., and Huang, R. 2009. Why Are Canadian Banks More Resilient? IMF: Washington.

Repullo, Raphael, 2003, Capital requirements, market power, and risk-taking in banking, Discussion Paper No. 3721, CEPR.

Roberta Romano. 2005. "After the Revolution in Corporate Law", Journal of Legal Education. 55(3): 342-259.

Senate. 2009. Report on Bank Mergers, Senate Economics References Committee. Canberra: AGPS.

Senate. 2011. Competition within the Australian Banking Sector. Senate Economics References Committee. Canberra: AGPS.

Schaeck, K.; M. Cihak; and S. Wolfe. 2009. “Are Competitive Banking Systems More Stable?" Journal of Money, Credit and Banking, 41, 711-734.

Stevens, Glenn. 2009. "Australia and Canada - Comparing Notes on Recent Experiences.” RBA Bulletin, June.

Takats, E. and Tumbarello, P. 2009, 'Australian Bank and Corporate Sector Vulnerabilities-An International Perspective', IMF Working Book. Washington: IMF.

Tett, Gillian. 2009. Fool's Gold: How Unrestrained Greed Corrupted a Dream, Shattered Global Markets and Unleashed a Catastrophe. New York: Little Brown Book Group.

Tickell, Adam. 2000. "Global Rhetorics, National Politics: Pursuing Bank Mergers in Canada." Antipode 32 (2): 152-175.

Treasury. 1996. Financial System Inquiry Submission. Canberra: AGPS.

Young, Kevin. 2013. "Financial Industry Groups' Adaptation to the Post-Crisis Regulatory Environment: Changing Approaches to the Policy Cycle." Regulation \& Governance 7 (4): 460-480. 